TAPROBANICA, ISSN 1800-427X. April, 2012. Vol. 04, No. 01: pp. 1-4.

(C) Taprobanica Private Limited, Jl. Kuricang 18 Gd.9 No.47, Ciputat 15412, Tangerang, Indonesia.

\title{
EDITORIAL
}

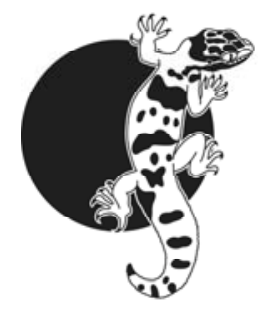

\section{How embarrassing can it get? Or: Taxonomy undermined}

\author{
Systematics is the science of the diversity of organisms (Mayr, 1969) \\ (Abbreviated from Simpson, 1961: "Systematics is the scientific study of the kinds and diversity of \\ organisms and of any and all relationships among them")
}

\section{Taxonomy is the theory and practice of classifying organisms (Mayr, 1969)}

Whereas biological systematics and taxonomy are probably about the same kind of scientific enterprise, they were separated by Ernst Mayr in his classical text book, and taxonomy became cemented as a subset of systematics. A little over 40 years have passed since these definitions were expressed, and the work in which they appeared has become obsolete with the appearance of new technology and new philosophy about what are the fundamental aspects of species and higher taxa, especially with the development of phylogenetic systematics and facility of studying factors of inheritance at molecular level. Nevertheless, biological systematics remains the fundamental powerful scientific domain for understanding and expressing biological diversity, and keeps its definitions.

Thus systematists employ taxonomic tools for naming and classifying organisms according to the results of research on phylogenetic relationships and species characteristics. In Zoology, naming is governed by the International Code of Zoological Nomenclature (International Commission on Zoological Nomenclature, 1999). Names proposed by systematists are used widely beyond the scientific domain, in legislation, in hobby, in commerce, and in lieu of popular names. The Code, together with its predecessors dating to the $19^{\text {th }}$ Century, has proven fully capable of being a stable framework for naming of animals, covering nomenclature from 1758 until today, and into the future. One would expect that the process of naming organisms would be carefully worked out by conscientious and responsible senior level scientists looking both to the good of society and the usefulness in the science domain of society.

Instead of finding nomenclature observed with seriousness, and taxonomy based on research and insightful experience with the taxa concerned, species taxonomy lamentably has to some extent become a playground for those infected by the pandemic mihi itch (Evenhuis, 2008), the illness that produces in its victim a craving to publish new names without doing the necessary background work, also known as nominomania (Trewavas, 1957). The problem here is that (a) by tradition, and provisions in the Code, scientific names of genera and species can have their authors' names appended to them; and (b) once a name has been made available according to the Code, it cannot be ignored, changed or reverted, no matter how mistaken the description or unidentifiable the species may be. The mihi itch is also expressed in restless renaming of junior homonyms (Trewavas, 1957).

In ichthyology, the mihi itch has mostly been identified in European and, to a lesser extent, North American aquarists. Aquaristic excursions in nomenclature were treated recently by Kullander (2011a). Inspiration for this editorial comes, however, from an unexpected source, from the recent surge in taxonomic student papers of very low quality, published in tropical countries, and mainly concerned with publishing supposedly new species. Why are they doing that? One explanation seems to be supervisors who somehow need papers and deliberately allow students to mess themselves up, the student taking all the risk of a curtailed career in biology. Another explanation may be that describing new species is considered such easy game for a publication that no training at all is needed. That shows up as embarrassing, for people, for nations, for science.

Supervisor co-authorship of student papers is not necessarily a bad thing, and usually the supervisor provides considerable intellectual matter for the final manuscript. One then also usually can expect the supervisor to have re-measured every fish and checked every word of the article. 
Particularly the taxonomy of groups of small fish species of interest to aquarists, already messy and difficult to analyze, is now made more intractable. There is no need here to point out any special person or taxon, however. Criticism of particular papers must be restricted to scientific publications, and should be backed up with facts. So far, there is very little of this matter, but see Kullander (2011b), and Řićan et al. (2011) for recent examples, and Trewavas (1946) for some more dated ones. It is relevant, however to reflect on what systematics is, what is required from descriptive taxonomy, and how taxonomic education can be boosted. Who can do taxonomy, for whom, and why?

Biological systematics is a scientific discipline, which requires scientific training - in biological systematics. For qualified work on taxonomy in any group, that usually means a $\mathrm{PhD}$ obtained under supervision of a major professor or other senior scientist. Even that is not a guarantee for quality work. One would need a few more research years to achieve sufficient familiarity with methods and organisms to be able to make useful impact. Why do some think they can do without the necessary scientific training? Lack of training of course limits understanding of the procedure; add to that the mihi itch, irresponsibility of supervisors, and deficient peer review. Not to forget the low status of taxonomy at universities and difficulty of finding the necessary training. To the unknowing, much of descriptive taxonomy also looks simple count a few fin rays and scales, make some proportional measurements, and a colour description, over with it.

Whereas a professional analysis commonly takes years to complete, especially because so much comparative material may need to be examined, it is indeed possible to get away with something done in 5 minutes by submitting some words and a photo of a fish to an aquarium magazine. Whereas the conclusions may be right or wrong, scientists and legislators may not have a clue to what species has been named. We now also see similar quick-and-dirty descriptions coming from academic addresses in biodiversity-rich countries. Are we at the brink of a major crisis in tropical fish taxonomy where aquarists, undergraduate students and others are deliberately producing would-be taxonomic work without adequate training even in writing a paper? Maybe it is high time to straighten up things, starting with editors, reviewers, and readers. Regain a very rigid scientific look at how taxonomy is performed and put as much requirement on taxonomic work as on any other scientific study. And look also at the responsibility involved in the privilege of being able to name things.

Systematic scientific ethics is partly formulated by the International Code of Zoological Nomenclature (International Commission on Zoological Nomenclature, 1999), which says, in Appendix D, Code of Ethics:

1. Authors proposing new names should observe the following principles, which together constitute a "Code of Ethics".

2. A zoologist should not publish a new name if he or she has reason to believe that another person has already recognized the same taxon and intends to establish a name for it (or that the taxon is to be named in a posthumous work). A zoologist in such a position should communicate with the other person (or their representatives) and only feel free to establish a new name if that person has failed to do so in a reasonable period (not less than a year).

3. A zoologist should not publish a new replacement name (a nomen novum) or other substitute name for a junior homonym when the author of the latter is alive; that author should be informed of the homonymy and be allowed a reasonable time (at least a year) in which to establish a substitute name.

4. No author should propose a name that, to his or her knowledge or reasonable belief, would be likely to give offence on any grounds.

5. Intemperate language should not be used in any discussion or writing which involves zoological nomenclature and all debates should be conducted in a courteous and friendly manner.

6. Editors and others responsible for the publication of zoological papers should avoid publishing any material which appears to them to contain a breach of the above principles.

7. The observation of these principles is a matter for the proper feelings and conscience of individual zoologists and the Commission is not empowered to investigate or rule upon alleged breaches of them. 
That can be considered minimal ethics for a taxonomist. Special responsibilities of scientists have been expressed recently by Bourne \& Barbour (2011), apparently with reason, and should be instructive for students in training in taxonomy. For the most part ethically sound behavior in science is just normal human behavior: Don't steal other people's ideas, don't omit citing relevant references (unless they would be embarrassing to that author, perhaps), don't submit manuscripts just to see if they get accepted despite errors and sloppiness, don't lie, don't cheat. And above all: learn the profession first. It certainly helps if one can avoid duplicate work and publish in one's own words instead of copying everything but a few details from other papers. In this journal, Dubois (2010) discussed the quality of taxonomic papers and how to properly name species, with numerous useful references; and Werner (2011) addressed the requirements of scientific writing. In short, a good paper has more than just a name and diagnosis; it has a soul, a purpose, and a life beyond future revisions. Scientific research is largely about communication.

It is the reader who is the important agent, the user of the information, not the paper, not the author. This is evident not least in my participation in the building of Fish Base (Froese \& Pauly, 2012) as an information system for all fishes. What do we do with nomenclatural scam? List it and hope somebody quickly revises it; hide it; or list it with reservations? Either way one risks spreading disinformation. The goal of Fish Base is to present only relevant and reliable information; the weak point then is bad taxonomy, and considerable effort goes into evaluating what information can actually be used in taxonomic papers. The problems we have, of course, are shared with others compiling information on biodiversity. It would be more natural if they all were scientifically sound and completely useful... And what we need and want are thorough revisions, not only more names.

Biodiversity rich countries in general are as poor (or poorer) in systematists who are experts on local fauna as North America and Europe. This has been pointed out by Skelton\& Swartz (2011) for Africa. In Brazil, on the other hand, as an excellent example of a positive development, the number of fish taxonomists is rather growing and the quality of the work is exemplary (Skelton \& Swartz, 2011). The explanation is partly in the availability of funding for research, as well as gifted biologists, but can also be traced to the expert training of the now leading Brazilian ichthyologists in excellent institutions in the United States and the continued collaboration of them and their students with European and North American colleagues. Personally, I believe that is the major lesson to be learned: engagement in and training in a rich academic context. We don't need "parataxonomists", or nominomanics, we need scientists able to integrate systematics, taxonomy and other biodiversity disciplines.

There are no shortcuts, no easy ways out or to avoid learning a profession, at least not if you need a good reputation to continue studies or apply for attractive positions. As a student, get yourself an experienced supervisor who is well recognized in the scientific community. Stay away from quick and dirty species descriptions. Learn the profession by doing revisions, using morphological and molecular methodology, learning as you move on. Publish only when you are ready.

An important function of the $\mathrm{PhD}$ period is to train the perceptive senses. More than a few ichthyologists have described to me how they worked for years discovering nothing, until finally characters kept started falling over them. It takes considerable training until one can actually see what is important. Neil Shubin in his early training as a field paleaeontologist put it simply: "I finally saw it" (Shubin, 2009). This is also my experience. Going from cichlids to cyprinids requires a completely new vision. Even shifting between African and South American cichlids requires a total restart of the way one looks for characters. No wonder very few people master more than one family or genus of organisms over an extended period.

Whereas some supervisors may disagree, student supervision is not about having an assistant helping with publication, but it is entirely about educating an independent scientist adhering to scientific principles, methodology, and ethics. This goal may be reached in numerous ways, including participation in the supervisor's project. Nevertheless, there are always points in time in a trainee's progress, when more training is required before a certain task can be entrusted to the student. And that is why $\mathrm{PhD}$ careers in general follow a plan with well-defined milestones and mid-term evaluation.

Nevertheless, it is quite clear that pressure to publish (or perish) is compromising all biological science. As seniors and supervisors, it is time to have a close look at this and work with editors, students, and authors to bring taxonomy back to the scientific high standard it requires. Having done all the mistakes hinted at here, and learned from them, my vision is that biological journals (editors, reviewers, readers) take a more serious attitude toward taxonomic work. One major goal of Taprobanica is indeed to promote professional taxonomic publication on Asian organisms (Amarasinghe, 2009). As a reader, you already 


\section{EDITORIAL}

support this goal. But we still want to hear your opinion about species taxonomy, and what you expect from species descriptions. Write to us at <thasun.taprobanica@gmail.com>

I am grateful to Roberto E. Reis and Colin Groves for constructive comments on the manuscript.

\section{Literature cited}

Amarasinghe, A. A. T., 2009. Editorial: An introduction to Taprobanica. Taprobanica, 1 (1): 1.

Bourne, P. E. and V. Barbour, 2011. Ten simple rules for building and maintaining a scientific reputation. PLOS Computational Biology, 7 (6): 1-2.

Dubois, A., 2010. Describing new species. Taprobanica, 2 (1): 6-24.

Evenhuis, N. L., 2008. The "Mihi itch" - a brief history. Zootaxa, 1890: 59-68.

Froese, R. and D. Pauly (eds.), 2012. FishBase. World Wide Web electronic publication <www.fishbase.org>, version (04/2012).

International Commission on Zoological Nomenclature, 1999. International Code of Zoological Nomenclature, Fourth Edition. International Trust for Zoological Nomenclature, London: xxix +306 .

Kullander, S. O., 2011a. Nomenclatural availability of putative scientific generic names applied to the South American cichlid fish Apistogramma ramirezi Myers \& Harry, 1948 (Teleostei: Cichlidae). Zootaxa, 3131: 35-51.

Kullander, S. O., 2011b. A review of Dicrossus foirni and Dicrossus warzeli, two species of cichlid fishes from the Amazon River basin in Brazil (Teleostei: Cichlidae). Aqua, 17: 73-94.

Mayr, E., 1969. Principles of Systematic Zoology. McGraw-Hill Book Company, New York: xi+428.

Říčan, O., L. Piálek, A. Almirón and J. Casciotta, 2011. Two new species of Australoheros (Teleostei: Cichlidae), with notes on diversity of the genus and biogeography of the Río de la Plata basin. Zootaxa, 2982: 1-26.

Shubin, N., 2009. Your inner fish. Penguin Books, London: ix +237 .

Simpson, G. G., 1961. Principles of Animal Taxonomy. Columbia University Press, New York: xii+247.

Skelton, P. H. and E. R. Swartz, 2011. Walking the tightrope: trends in African freshwater systematic ichthyology. Journal of Fish Biology, 79: 1413-1435.

Trewavas, E., 1946. The types of African cichlid fishes described by Borodin in 1931 and 1936, and of two species described by Boulenger in 1901. Proceedings of the Zoological Society of London, 116, part II: 240-246.

Trewavas, E., 1957. Nominomania. Annals and Magazine of Natural History (12), 10: 349-350.

Werner, Y. L., 2011. Editorial: A splitter's systematics of writing: scientific writing and writing English are separate issues and this has implication. Taprobanica, 3 (1): 1-4.

Sven O Kullander

Sectional Editor: Taprobanica, the journal of Asian Biodiversity

May $3^{\text {rd }}, 2012$

Associate Professor, Department of Zoology, Stockholm University

Senior Curator of Ichthyology \& Herpetology

Swedish Museum of Natural History

P.O. Box 50007, SE-104 05 Stockholm

SWEDEN 